\title{
The Refusal of Livestock Owners Towards Exclusion Policy In Protected Area
}

\author{
Rahman Kurniadi ${ }^{1}$, Herry Purnomo ${ }^{2}$, Nurheni Wijayanto ${ }^{2}$, Asnath Maria Fuah ${ }^{3}$
}

'Graduate School of Bogor Agricultural University, Campus IPB Dramaga, Bogor, Indonesia 16680

${ }^{2}$ Faculty of Forestry, Bogor Agricultural University, Campus IPB Dramaga, PO Box 168, Bogor, Indonesia 16680

${ }^{3}$ Faculty of Animal Science, Bogor Agricultural University, Campus IPB Dramaga, Bogor, Indonesia 16680

Received November 30, 2016/Accepted March 30, 2017

\begin{abstract}
Development of protected forest is often considered to be a way to preserve biodiversity and ecosystem service. To keep protected area, Indonesia government excludinged local people from protected forest by making a policy which prohibits grazing on protected forest. However, the success of protected forest management often depends on perception of local people because the policy has affected livestock owners who have interest in forest use. Exclusion of local people from protected forest leads loss of people income and unemployment. This study applied a socioeconomic approach to examine and analyze the livestock owner perception on forest grazing prohibition in Timor Island of Indonesia by conducting a household survey of 36 livestock owners. The study results showed that $30.6 \%, 50.0 \%, 19.4 \%, 0 \%$, and $0 \%$ of livestock owners are totally disagree, disagree, neutral, agree, and totally agree, with grazing prohibition, respectively. In addition, people perception was significantly affected by number of livestock owned by people. It means that livestock owners mostly reject the policy on grazing prohibition. Indeed policy which prohibits grazing on the protected forest is not effective to be implemented. Government and policy maker should review the policy and consider the refusal of livestock owner toward exclusion policy. Interest of local people should be considered in developing a policy on protected forest.
\end{abstract}

Keywords: perception, Gunung Mutis, protected forest, timor, forest grazing, silvopasture

*Correspondence author; email: rahmankurniadi@gmail.com, ph./fax:+62-380-823357/+62-380-631068

\section{Introduction}

Indonesian Government has classified state forest into three categories namely protected forest, conservation forest, and production forest. In the protected forest and conservation forest, the government has prohibited forest grazing. This policy happens in all provinces without considering local people context. In some area, the policy couldnt be implemented because the local people have rejected the policy.

Paletto et. al. (2013) stated that individual perceptions are becoming to increase appropriatey as a central component of social and environmental sustainability. An analysis of people perceptions is vital to participate in forest planning and management because individual knowledge has the potential to support effectively the decision-makers in the management and preservation of forest resources. According to Dolisca (2007), a better consideration of rural people knowledges on forest, their awareness of deforestation and perceived impact on their socio-economic and environmental welfare, are vital to the development and implementation of management strategies that are both sustainable and sensitive to the existing local needs.

Humans are dependent on ecosystems and their abilities to provide services contribute to well-being. However, sometime we face the loss of ecosystem service because of anthropogenic activities (Mutiso et al. 2013). Local people are considered as a cause of loss of ecosystem service (Contreras-Hermosilla 2000). Livestock owners are considered as a cause of forest degradation in Gunung Mutis.

Protected areas can enforce economic costs on local communities by limiting their ability to use forests for agriculture, logging, and hunting. But they can also supply economic benefits by spurring tourism, attracting infrastructure investments, and ensuring the continued provision of valuable forest ecosystem services (Ferraro 2008; Ferraro \& Hanauer 2011). So that, the government sometimes exclude the local people from forest to sustain the protected forest.

Local people are the important stakeholder to implement the suitable forest management (Silvano 2005). Livestock owners are key actors in actively using, changing, and managing the forest. Therefore, livestock owners must be included in management procedures (Gunawan et al. 2004). However, local people often are not supportive to the policy that prohibits forest grazing because of their limit access to forest, and they create human-wildlife conflicts (Sodhi et al. 2008). There is a conflict between protected area and local people. Sodhi et al. (2010) stated that the local people need to be aware of the purported benefits of nature because the effective conservation hinges on garnering support. 
Although scarce and fragmented, Nusa Tenggara forests are important at the local, regional, and international levels. At a local level, communities use forest areas as grazing lands for livestock as well as a source of income supplements, building materials, and fuel-wood. Given an arid climate, forested areas play a critical regional role as water catchment, in Nusa Tenggara especially at the steep and mountainous locations. The unique ecology, their high levels of endemic species and biodiversity of forested area attract international interest to their conservation. The government of Indonesia has declared several areas attracting international interest such as national parks and nature reserves (Lentz et al. 1998).

Beside the importance of the forest to local communities as an area for livestock grazing, the forest also plays a significant role as a source of income supplements, water supply, building materials, and fuel-wood. Income supplements consist of the income of collecting honey from wild bee nests and valuable timber forest products such as sandalwood in Gunung Mutis. Water is piped from springs in the forest to households for cooking, drinking, bathing, etc. Building materials and fuel wood are collected from the dried trunks and branches of naturally fallen Ampupu trees (Lentz etal. 1998).

Local people depend on the natural resources of the conservation area (Eghenter 2000). There has been an increasing emphasis on (a) the participation of local people in management of conservation areas and (b) the need to balance conservation priorities with the development needs of the communities living in and around the conservation area. Evidence from anthropological, human ecological, and archaeological studies had shown that local people in certain cases had played an important role in preservation of specific environments and that human-induced disturbances had been part of natural landscape (Headland 1997). There was a conflict between protected area and local people forest because of different protection priorities of natural resources and economic development (Wells \& Brandon 1992). Many villagers depend on raising dairy cattle as their main source of income in Timor Island.

Indonesia government has established the protected forest in Gunung Mutis, Timor Island since 1974. A policy that prohibits grazing was made to keep the protected forest. Establishing the protected area limited grazing activities on the forest, so the forest can be maintained. However, protected areas enforce economic cost on local communities and decrease income of local people (Ferraro 2008).

Forest decline is the result of actions by a number of agents. Agents are individuals, groups of individuals or institutions that directly convert forested lands to other uses or that intervene in forests without necessarily causing deforestation but substantially reducing their productive capacity. Agents include shifted cultivators, private, and government logging companies, mining, oil, farming corporations, forest concessionaires, and ranchers. These agents clear the forest lands or selectively exploit the forests for agricultural expansion, survival, mining, forest products, and fuel-wood, etc (Contreras-Hermosilla 2000).

Local communities were highly dependent on the ecosystem. They perceived ecosystem benefit of provision of raw materials, prevention against natural disasters, climate regulation, and soil retention. Encroachment and illicit felling were identified as the main causes of such degradation. In order to stop the continuing degradation which is allowed by conventional forest management flaws, the adaptive co-management has been recommended to conserve this ecosystem in a more equitable way (Iftekhar \& Takama 2008).

Rural communities exploit forests in unsustainable ways in searching profits and survival. These are the primary actors in forest decline and their immediate motivations are the direct causes of deforestation and degradation (Contreras-Hermosilla 2000). There are some important stakeholders in such programs (Purnomo et al. 2012). Rural communities exploit grass growing in forest and they donot aware about forest sustainable in the some forest areas.

Indonesian government has made a ruler that prohibits grazing on forest area to establish sustainable forest with alternative sources of preferable ecosystem services that fulfill conservation objectives and reduce poverty. We need information about the perceptions of local people regarding forest policy. The information about local people's perception is useful for considering policy implementation.

Perception of local people affects forest sustainability. People who perceived sustainable forest benefit tend to support in keeping forest. In contrast, local people who do not perceive forest benefit tend to decline forest. Perception of local people is affected by socio-economic factors (Tortop 2012). Muhamad et. al. (2014) found that interest of local people affects their perception.

Gunung Mutis forest is located in Timor Island, Indonesia. It faces the pressure of local people. There are 16 districts and 102,612 heads of livestock surrounding Gunung Mutis Forest (Indonesia Central Bureau of Statistics 2016). The number of family surrounding Gunung Mutis forest is 36.470 families. Local people graze for their livestock on forest.

Livestock owners use protected forest for feeding their livestock in Timor Island. Livestock owners are affected by the policy that prohibits grazing on protected forest in Timor Island. The implementation of a policy that prohibits grazing on protected forest depends on perception of livestock owners. Moreover, socio-economic characteristic affects local people perception on forest conservation (Qua et al. 2012).

There are many researchs about protected forest but there is limited information about people perception on forest policy. We investigated the policy related to people livelihood and examined how the policy was implemented. Our objectives were to (1) determine the effects of socioeconomic status on their perceptions on forest grazing prohibition and (2) analyze relationship between livestock owner perception and forest grazing policy.

\section{Methods}

Theoretical framework Theoretical framework used (Figure 1) was developed by Institute Development Studies (IDS) in 2006 to examine relationship between perception and policy implementation. To analyze policy implementation, IDS developed and elaborated a simple 


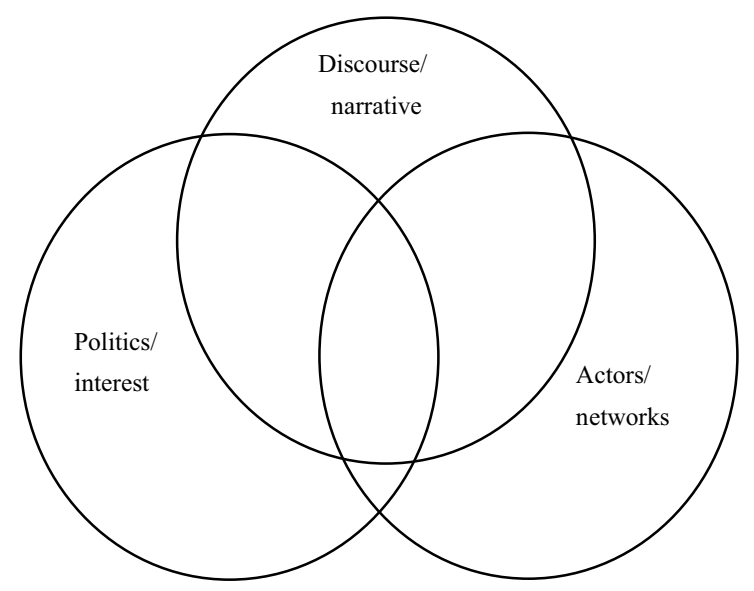

Figure 1 Theoretical framework for analyzing policy processes.

framework linking three interconnected themes such as knowledge and discourse (what is the 'policy narrative' how is it framed through sciencetific research, etc); actors and networks (who is involved and how they are connected), and politics and interests (what are the underlying power dynamics). The policy narrative is that the government of Indonesia has prohibited forest grazing on conservation forest and protected forest. Actors related forest grazing are livestock owners, government, and other actors. Income is interest of livestock owners, but ecological services are interest of Indonesian government.

The policy literature states that policy implementation is mainly driven by actors' beliefs, values, and experience. Actors' core beliefs comprise distinct sets of policy goals, perceptions of problems and their causes, and preferences for problem solutions (Sotirov et. al. 2016). Because individual knowledge has the potential to effectively support the decision-makers in the management and preservation of forest resources, an analysis of people perceptions is fundamental to participatory forest planning and management (Paletto et al. 2013)

Study area The study (Figure 2) was carried out in two villages of Timor Island, Indonesia namely Fatumnasi and Tune. The main criterion for village selection was proximity to protected forest. Fatumnasi and Tune were all located near Gunung Mutis Protected Forest. Some of households in Fatumnasi and Tune Village use protected forest for grazing their livestock. According to Indonesian Statistics Bureau (2016), the number of households in the villages is altogether approximately 527 .

Gunung Mutis protected forest is located in Timor Island, Indonesia. The island of Timor, northwest of Australia, is the largest and the most eastern of the Lesser Sunda Islands. The island of Timor covers an area of $28,000 \mathrm{~km}^{2}$ and is the largest of the many islands located in the Eastern Indonesian archipelago of Nusa Tenggara. Cultural traditions are diverse and strong among the population of Nusa Tenggara, and the majority of people livelihood sources is agriculture and

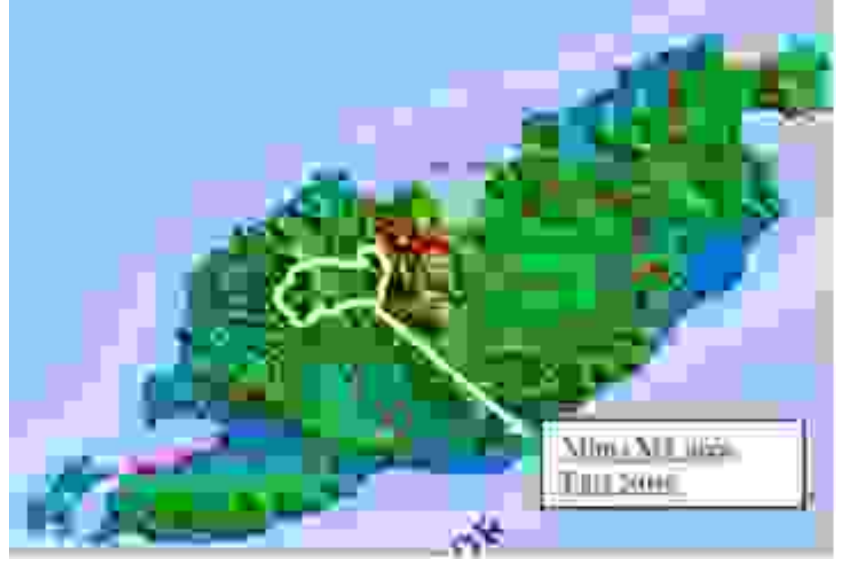

Source: ITTO 2013

Figure 2 Location of Gunung Mutis forest.

raising livestock. Infrastructure such as roads and electricity are available to only a small portion of the population and their access to health care, education, and other services are very limited (ITTO 2013). Timor belongs to the transitional border area between the Oriental and Australian Regions, frequently called Wallacea (Lohman et al. 2011). The 115,380 hectares of the unique Gunung Mutis $(2,427 \mathrm{~m})$ is dominated by homogenous stands of Eucalyptus urophylla. The forested slopes of Gunung Mutis, the locality type of the new species, are a critical watershed for Timor Island and play a strong role in the culture and economy of several villages located in and around Gunung Mutis (Lentz et. al. 1998).

Indonesia government has designated Gunung Mutis area as state forest in 1974. High grazing pressure and repeated fires occurred in Gunung Mutis forest (Dickinson et al. 2000). There are 16 districts and 102,612 heads of livestock surrounding Gunung Mutis Forest (Indonesia Central Bureau of Statistics 2016).

Data collection A simple random sample of 36 livestock owners (5\% of the livestock owners) was selected by using the Random Number Generator Program. The data were collected by conducting personal interviews of the livestock owners by using a structured questionnaire. Data collection was conducted on April-June 2016. Moreover, the data were also collected through focused group discussion sessions which were attended by 10 persons including representatives from the head of village, farmers, and livestock owners. The sessions were intended to solicit the participant opinions about the important uses of forest, investigate reasons for grazing on forest, and enlist the suggestions for protected forest conservation.

Descriptive statistics (frequency distribution, mean, and standard deviation) and Kruskal-Wallis tests were used to analyze the data. The Kruskall-Wallis tests were used to elucidate socio-economic factors which affect livestock owner perceptions on grazing prohibition. 
Table 1 Socio-economic differences of sampled respondents $(\mathrm{n}=36)$

\begin{tabular}{lc}
\hline Socio-economic variable & Percentage \\
\hline Age & 0 \\
$<20$ & 22.2 \\
$20-40$ & 69.4 \\
$41-60$ & 8.4 \\
$\geq 61$ & \\
& \\
Family size & 36.1 \\
$<5$ & 50.0 \\
$5-6$ & 13.9 \\
$\geq 7$ & \\
& \\
Educational level & 69.4 \\
Primary school & 5.6 \\
Intermediate school & 25.0 \\
High school & 0 \\
University & \\
& \\
Marital status & 100 \\
Married & 0 \\
Single & \\
1-2 & 38.9 \\
$3-4$ & 22.2 \\
$\geq 5$ & 38.9 \\
\hline
\end{tabular}

\section{Results and Disscusion}

Characteristics of the respondents The findings of the study (Table 1) indicated that no respondent was less than 21 years of age and $22.2 \%$ of respondents were between the age of 21 and 40 years. The respondents who were more than 61 year of age represented only $7.5 \%$ while $69.4 \%$ of respondents were between the age of 41 and 60 years. The study revealed that people were less than 21 years of age had no livestock. Generally, they are students and have no occupation. Therefore, they have no livestock.

Mostly livestock owners were between 40 and 60 years old. The people must have experience to be a raiser. People who were 40 years have more experiences in raising livestock. Therefore, they are interested in having livestock. People who were less than 40 years old age is not enough experience in raising livestock.

According to research, $69.4 \%$ of the respondents were with primary school education, and $5.6 \%$ of respondents had received their intermediate school education. The respondents who were with high school were $25 \%$. No respondent was with university education. Generally, people with university education do not want to become a livestock raiser. They prefer to go to urban to be employee in government or private sector. The result findings were in line with Muhamad et. al. (2014). They showed that rural people mostly received primary school educational level.

Mostly, rural people have primary school education in Indonesia. They work as small farmer and livestock raiser. Small farmer and raiser are chosen if they do get any job and people with university education choose other jobs. Approximately, $36.1 \%$ of the respondents had the families with less than five members and $50 \%$ of respondents comprised of 5-6 members. Only $13.4 \%$ of the respondents were having more than 6 members in their families. Most of people living close to forest had the families 5-6 members so there was a positive growth of population. Therefore, population pressure on forest increases every year.

Livestock owner perception Indonesia government made a policy that prohibits grazing on protected forest to maintain protected forest. The policy has affected livestock owners who have interest on protected forest. They usually graze their livestock on protected forest. They will loss the source of income if they are prohibited to graze livestock on forest.

The mean and the standard deviations of the livestock owner perception on grazing prohibition are divided into five point scales (1:totally disagree; 2 :disagree; 3 :neutral; 4:agree ; 5 :totally agree), that are presented in Table 2 . The findings of the study (Table 2 ) indicate that $30.6 \%$ of respondents are totally disagree with grazing prohibition, $50 \%$ of respondent disagree and $19.4 \%$ respondents neutral with grazing prohibition. There is no respondent who agrees and totally agree on grazing prohibition.

\section{Factors influencing livestock owner perception \\ 1 Number of livestock}

Chi-square test (Table 3) was used to determine the differences between the respondent livestock number and their perception on grazing prohibition. The study revealed statistically that there were significant differences between the respondent livestock number and their perception on grazing prohibition $(\mathrm{p}=0.032$ at the 0.05 level of significance).

The research found that the number of livestock had influence in shaping the respondent perception of grazing prohibition. Livestock owners who had more than two heads of livestock tend to disagree with grazing prohibition because they need forest for grazing their livestock. However, respondents who had less than tree heads of livestock tend to be neutral with grazing prohibition because they do not depend on forest to feed their livestock. They use their yard to feed their livestock.

2 Education

The findings of the present study showed that there was no significant difference between respondent education level and their perception on grazing prohibition (Table 4). Respondents were with primary school education, intermediate education and high school education had similar perception on grazing prohibition. They disagree with grazing prohibition. These findings are not in line with Tortop (2012) and Alsubaiee (2016) who found that education has a great impact on creating awareness regarding the importance of forest conservation. Based our finding, effect of educational level on perception on grazing prohibition is unsignificant.

3 Family size

The finding of the present study showed that there was no significant difference between respondents who had the families with members, the respondents with five 
and six members and the respondents with more than six members, and their perception on grazing prohibition (Table 5). Family size does not affect livestock owner perception on grazing prohibition. People who had family with less than five members and people who had family with more than five members have the same interest. They need forest for grazing their livestock.

The research findings showed that family size does not affect significantly to perception of livestock owners. However, livestock owners who have families more than 2 people can create more livestock owners in the next time. Government faces more problems in Gunung Mutis Forest if the increase of livestock owner number occurs in surrounding forest. More forest area must be provided to meet the need of livestock owners. In addition, livestock owners who have big number of families create more unemployment in surrounding forest. Therefore, they cause forest decline (ContrerasHermosilla 2000).
4 Age

The findings of the present study showed that there was no significant difference between respondents who were $<41$ year of age, $41-61$ years, and $>61$ year of age, regarding their perception on grazing prohibition (Table 6). They need protected forest for grazing their livestock. Therefore, they have the same perception. They disagree on grazing prohibition.

Factor affecting livestock owner perception The study showed that livestock number of respondent affected significantly to the perception of respondents. However, age, education, and family size of respondent has no influence on respondent perception. The research does not in line with Hasan et. al. (2002) and Hasan (2008) who stated that the way of thinking, attitudes, perceptions, and behavior of the people toward the adoption of innovations were influenced by socio-economic characteristics such as age, education, occupation, marital status, number of livestock, and number

Table 2 Perception on grazing prohibition in forest (\% of respondents), $\mathrm{N}=36$

\begin{tabular}{|c|c|c|c|c|c|c|c|}
\hline \multirow[t]{2}{*}{ Perception } & \multicolumn{7}{|c|}{$\%$} \\
\hline & $\begin{array}{l}\text { Totally } \\
\text { disagree }\end{array}$ & Disagree & Doubt & Agree & $\begin{array}{l}\text { Totally } \\
\text { agree }\end{array}$ & Mean & $\begin{array}{l}\text { Deviation } \\
\text { standart }\end{array}$ \\
\hline On forest grazing prohibition & 30.6 & 50.0 & 19.4 & 0 & 0 & 1.89 & 0.708 \\
\hline
\end{tabular}

Table 3 Kruskal-Wallis test for respondent perception differences based on their livestock number

\begin{tabular}{lccccc}
\hline & Livestock number & $\mathrm{N}$ & $\begin{array}{l}\text { Mean } \\
\text { rank }\end{array}$ & Chi-square & Asymp sig. \\
\hline Perception & $1-2$ & 14 & 23.79 & 6.881 & 0.032 \\
& $3-4$ & 8 & 14.81 & & \\
& $\geq 5$ & 14 & 15.32 & & \\
\hline
\end{tabular}

Table 4 Kruskal-Wallis test for respondent perception differences based on their education

\begin{tabular}{llrlll}
\hline & Educational level & N & $\begin{array}{l}\text { Mean } \\
\text { rank }\end{array}$ & Chi-square & Asymp sig. \\
\hline Perception & Primary school & 25 & 20.52 & 3.593 & 0.166 \\
& Intermediate school & 2 & 13.25 & & \\
& High school & 9 & 14.06 & & \\
\hline
\end{tabular}

Table 5 Kruskal-Wallis test for respondent perception differences based on their family size

\begin{tabular}{llllcc}
\hline & Family size & $\mathrm{N}$ & $\begin{array}{l}\text { Mean } \\
\text { rank }\end{array}$ & Chi-square & Asymp sig. \\
\hline Perception & $<5$ & 13 & 19.88 & 0.419 & 0.811 \\
& $5-6$ & 18 & 17.75 & & \\
& $\geq 7$ & 6 & 17.60 & & \\
\hline
\end{tabular}

Table 6 Kruskal-Wallis test for respondent perception differences based on their age

\begin{tabular}{rrrrrc}
\hline & Age & N & $\begin{array}{l}\text { Mean } \\
\text { rank }\end{array}$ & Chi-square & Asymp sig. \\
\hline \multirow{2}{*}{ Perception } & $21-40$ & 8 & 20.00 & 1.816 & 0.403 \\
& $41-60$ & 25 & 17.28 & & \\
& $\geq 61$ & 3 & 24.67 & & \\
\hline
\end{tabular}


of family members.

Perceptions are likely to differ among people living in different landscapes because of the various cognitive aspects of the reception of visual stimuli and the implicit categorization underlying people interpretations of the surrounding environment based on their experiences with nature (Berkes 1999). The research finding showed that people in the same place tend to have same perception because they are affected by other people who live together. They have the same experiences which affect cognitive aspect. Therefore, age, number of families and education do not affect livestock owner perceptions.

The research findings showed that livestock number of respondent affects the perception of respondent. The finding is in line with Muhamad (2014) who stated that livestock number affected respondent perception. Respondent perception is related to interest of respondent to graze livestock on the forest. Respondents who have more than two livestock could not raise livestock in the stall because they have limited workers for feeding livestock. They need forest for grazing livestock.

Clements et al. (2014) found that protected areas have some positive impacts on households that use forest and land resources for their livelihoods. Households living close to forest get benefit from forest in Gunung Mutis. There are grasses that grow beneath tree and pasture areas on the Gunung Mutis protected forest area. Respondent who had more two livestock feed their livestock by grazing their live stocks on protected forest area. Feeding livestock by grazing needs less number of workers than feeding by cutting grass. Therefore, they can raise more livestock on forest. Livestock owners prefer to graze their livestock on the forest than cutting grass because financial benefit of grazing on the forest is bigger than financial benefit of cutting grass.

Generally, households raise livestock for source of their income. Some of households feed their livestock by cutting grass. Livestock owners who have less than three heads of livestock raise their livestock on stall. They use their family as workers. Feeding livestock by cutting grass need workers. One household can only feed two livestock. Generally they raise male cattle in the stall because male cattle has high price. However, they graze female cattle on forest because female cattle have low price and low productivity.

The research findings showed that age do not affect significantly in perception of livestock owners because they have the same perception. The findings are in line with Muhamad (2014) who stated that age had a little influence in shaping perception of local people on ecosystem service because they have the same interest in forest use. Livestock owners who were $<40$ years old of age and people who were $\geq 40$ years old of age have the same interest. Therefore the have the same perception to reject grazing prohibition.

Most of livestock owners were 40 years old of age or more. They tended to graze their livestock on the forest area because they need less workers to keep their livestock. In contrast, some livestock owners raise their livestock in the stall which need more workers for cutting grass. Livestock owners who were 40 years old of age like a raising system which needs less number of workers.

Most farmer and livestock raiser were old people and with low educational level. Young people and people who were with high educational level do not want to be small livestock raiser. They go to urban to search formal employee. They become livestock raisers if they dot get any job. Therefore, most people in rural were old people and low educational level.

Sodhi et al. (2009) found that education level has some influences on people environmental awareness. However, the research found that education level has not influenced on people environment awareness because livestock owners who get different educational level have the same interest. They need forest for grazing their livestock. The research findings are in line with Muhamad et. al. (2014). They found that educational level had little influence in shaping people perception of ecosystem service. Therefore, Sodhi et. al. (2012) suggests to give conservation education to local people for shaping local people awareness.

Generally, livestock owners have low level education in Timor Island. Households who have received high level education do not want to be a small raiser. They go to urban and search a formal occupation. Therefore, generally households who live close to forest are the households who have received low education.

Some previous study revealed that education level affected perception of local people (Tortop, 2012). They are suggested to increase their educational level to shape local perception. They showed that increasing educational level of local people caused perception of local people on ecosystem more positive. However, result findings showed that grazing on the forest was practiced by local people who have both low and high educational level.

Livestock owners have the same interest although they have received different educational level. They need forest to feed their livestock. They have the same perception on grazing prohibition because they have the same interest. Most of livestock owner disagree with grazing prohibition.

Forest grazing policy and livestock owner perception The research showed that the theoretical framework developed by IDS (2006) is useful for analyzing forest policy. There are relationship between policy narrative, actors, and interest of actors. Livestock owner perception and interest of livestock owners affect policy narrative which states that forest grazing is prohibited. Therefore, the policy cannot be implemented.

The findings of the present study showed that livestock owners had negative perception on forest grazing prohibition. This causes the policy which prohibits grazing on Gunung Mutis forest cannot be implemented. The finding is in line with Paletto et. al. (2013) who states that local people perception has the potential to effectively support the decision-makers in the management and preservation of forest resources.

Indonesia government believes that grazing on forest causes protected forest decline so it makes a ruler that prohibits grazing on the forest area. However, most of livestock owners disagree with the ruler and they continue grazing their livestock on the forest area. Conflict between government and livestock owners is emerging because of the different perception between ecosystem priorities and community need priorities (Wells \& Brandon 1992). There are grasses which are needed by livestock owner on the forest 
area, but government prohibits local people to graze their livestock on the forest area.

The research found that livestock owners perceived that grazing prohibition limited their livelihood so they tended to be more negative. The research was consistent with Dolisca (2007) who stated that respondents who believed that their farming activities would be disadvantage from forestry programs through forest protection tended to be more negative.

Local people are highly dependent on natural resources of conservation area (Eghenter 2000). Livestock owners disagree with grazing prohibition because they need area for grazing their livestock. Interest of livestock owners affects their perception on using forest.

There is a different interest between government and local people. Government interest is to keep forest for providing ecosystem service but local people interest is to use forest for grazing their livestock. Mostly, government and local people have different interest. According to IDS (2006), interest affects implementation of a policy. The policy could be supported by local people if government and local people have the same interest.

Communities are able to identify their perception and services that they need (Fagerholm et al. 2012). Such perceptional differences among different end users of ecosystem services may cause conflicts over natural resource management. In order to harmonize the inter relation between humans and nature and to establish sustainable forest management, it is important to understand the various perceptions of local people in different socio-economic conditions (Muhamad 2014).

Livestock owner do not support grazing prohibition because they need income for their life. However, there is no occupation surrounding forest. They will loss their livelihood if they are prohibited to graze on the forest. Therefore, they disagree with the rule of grazing prohibition on the forest. The research is consistent with Gunawan (2004) who states that policies which are aimed to exclude the local communities from forest management are inappropriate, especially in a densely populated area with a low level of land ownership. Silvo-pasture system which allows livestock owner to graze their livestock on the forest area is an alternative to meet ecosystem services and livestock owner need.

Government of Indonesia faced unemployment problem around forest. Most of unemployment people in rural area are young people. They can be a traditional farmer and raiser. However, there are not enough land for farming and grazing so they use forest for grazing purpose. Government must provide forest land to solve this problem.

Government of Indonesia must keep the forest sustainability and livestock owner's need. Recently, the government excluded livestock from the forest to keep forest sustainability. This way causes unemployment increased and income loss of local people. The alternative way to sustain forest and give income for local people is developing silvopasture. Silvo-pasture area can address the need of local people and sustain the forest.

Establishing forest grazing area or silvo-pasture area addresses ecosystem benefit and social benefit. In this way, government of Indonesia lets livestock owner to graze their livestock on the forest area. However, they must keep growing trees on the forest. Silvo-pasture area must be limited to keep forest sustainable. Recently, there is no silvo-pasture area in Gunung Mutis forest. However livestock owners graze their livestock without limited area and they do not manage their livestock to meet sustainability of forest.

Government of Indonesia has faced people who have negative perception on forest grazing policy in Gunung Mutis forest. There are two ways to solve this problem. The first is changing people perception by educating the people. The second is reviewing the policy and providing area for grazing. Currently, the former is difficult to conduct however the latter can be accepted to solve the problem. In addition, government must improve the management of forest grazing in Gunung Mutis.

\section{Conclusions}

The research findings reveal that livestock owners disagree with forest grazing prohibition because they need forest for grazing their livestock. Therefore, a policy which prohibits grazing in the forest is not effective to be implemented. The number of livestock owned by households is a factor affecting perception on grazing prohibition. However, age, education, and family size of local people are not significantly affecting perception of livestock owners on forest grazing prohibition. Based on the research, the government is suggested to consider the local context in making policy related to forest grazing in Gunung Mutis forest.

\section{References}

Alsubaiee FS. 2016. Socio-economic factors affecting the conservation of natural woodlands in central riyadh area-saudi arabia. Saudi Journal of Biological Sciences 23:319-326. http://dx.doi.org/ 10.1016/j.sjbs.2015.02.017.

Berkes F. 1999. Sacred Ecology: Traditional Ecological Knowledge and Resource Management. Philadelphia: Taylor \& Francis.

Clements T, Suon S, Wilkie DS, Gulland MEJ. 2014. Impacts of protected areas on local livelihoods in Cambodia. World Development 64:125-134. http://dx.doi.org/10.1016/j.worlddev.2014.03. 008

Contreras-Hermosilla A. 2000. The Underlying Causes of Deforestation. Occasional Paper No. 30. Jakarta: Centre for International Forestry Research (CIFOR).

Dickinson EC, Rasmussen PC, Round PD and Rozendaal F. 2000. Systematic notes on Asian Birds. A review of the russet bushwarbler Bradypterus seebohmi (Ogilvie-Grant, 1895). Zoologische verhandelingen 331:11-64. 
Dolisca F, Mcdaniel JM, Teeter LD. 2007. Farmers' perceptions towards forests: a case study from Haiti. Forest Policy and Economics 9:704-712. http://dx.doi. org/10.1016/j.forpol.2006.07.001

Eghenter C. 2000. Mapping Peoples Forests: The Role of Mapping in Planning Community-Based Management of Conservation Areas in Indonesia. Washington DC: Biodiversity Support Program.

Ferraro P, Hanauer M, Sims K. 2011. Conditions associated with protected area success in conservation and poverty reduction. Proceedings of The National Academy of Science 108(34):13913-13918. https://doi.org/10.1073/ pnas. 1011529108.

Ferraro P, Hanaue M. 2011. Protecting ecosystems and alleviating poverty with parks and reserves: "win-win" or tradeoffs? Environmental and Resource Economics 48(2):269-286. https://doi.org/10.1007/s10640-0109408-z

Ferraro P, Hanauer M, Miteva D, Canavire-bacarreza GJ, Pattanayak S, Sims K .2013. More strictly protected areas are not necessarily more protective: evidence from Bolivia, Costa rica, Indonesia, and Thailand. Environmental Research Letters 8(2):1-7. https://doi. org/10.1088/1748-9326/8/2/025011.

Fagerholm N, Käyhkö N, Ndumbaro F, Khamis M, 2012. Community stakeholders' knowledge in landscape assessments: mapping indicators for landscape service. Ecological Indicators 18:421-433.

Gunawan B, Takeuchi K, Tsunekawa A, Abdoellah OS. 2004. Community dependency on forest resources in West Java, Indonesia. Journal of Sustainable Forestry 18:29-46. https://doi.org/10.1300/J091v18n04_02.

Hassan MZY. 2008. Analysis of the Obstacles to Gender Mainstreaming in Agricultural Extension in the Punjab Pakistan: A Case Study of District Muzaffargar. http://prr.hec.gov.pk/thesis/2327.pdf. [accessed June 12, 2016].

Hassan MZY, Siddiqui BN, Irshad MN. 2002. Effect of socioeconomic aspects of mango growers on the adoption of recommended horticultural practices. Pakistan Journal of Agricultural sciences 39:20-21.

Headland T.1997. Revisionism in ecological anthropology. Current Anthropology 38(4):605-650.

IDS. 2006. Understanding Policy Processes A Review of IDS research on the Environment. Knowledge, Technology and Society Team. UK: Institute of Development Studies at the University of Sussex Brighton BN19RE. https://doi.org/10.1086/204648.

Iftekhar MS, Takama T.2008. Perceptions of biodiversity, environmental services, and conservation of planted mangroves: a case study on Nijhum Dwip Island,
Bangladesh. Wetlands Ecology and Management 16:119-137. https://doi.org/10.1007/s11273-007-90608.

[ITTO] The International Tropical Timber Organization. 2013. Participatory Forest Management for Sustainable Utilization of Non Timber Forest Products (NTFP) surrounding the protected area of Rinjani and Mutis Timau Mt, Nusa Tenggara, Indonesia. Jakarta: ITTO.

Indonesia Central Bureau of Statistics. 2016. Nusa Tenggara Timur in Figure. Kupang: Badan Pusat Statistik Kupang.

Lentz C, Mallo M, Bowe M. 1998. Environmental management in Gunung Mutis: a case study from Nusa Tenggara, Indonesia. Presented in the International Association for the Study of Common Property, 10-14 June 1998, Vancouver, BC, Canada

Lohman DJ, De M, Page T, Von RK, Hall R, Ng PKL, Shih HT, Carvalho GR. Von RT. 2011. Biogeography of the Indo-Australian archipelago. Annual Review of Ecology, Evolution and Systematics 42: 205-226. https://doi.org/ 10.1146/annurev-ecolsys-102710-145001.

Muhamad D, Okubo S, Harashina K, Parikesit, Gunawan B, Takeuchi K. 2014. Living close to forests enhances people's perception of ecosystem services in aforest-agricultural landscape of West Java, Indonesia. Ecosystem Services 8:197-206.

Mutiso FM, Hitimana J, Kiyiapi JL Sang FK, Eboh. 2013. Rainforest from anthropogenic disturbances. Journal of Tropical Forest Science 25(4):566-576.

Paletto A, Meo ID, Cantiani MG. Social Perceptions and Forest Management Strategies in an Italian Alpine Community. Mountain Research and Development 33(2):152-16. https://doi.org/10.1659/MRDJOURNAL-D-12-00115.1.

Purnomo H, Suyamto D, Abdullah L, Irawati RH. 2012. REDD+ actor analysis and political mapping: an Indonesian case study. International Forestry Review 14(1):74-88. https://doi.org/10.1505/14655481279997 3208 .

Qua M, Ahponen P, Tavanainen L, Gritten D, Molayudego B, Pelkonen P. 2012. Practices and perceptions on the development of forest bioenergy in china from participants in national forestry training courses. Biomass and Bioenergy 40:53-62. https://doi.org/10. 1016/j.biombioe.2012.01.050.

Shrestha RP, Ligonja PJ. 2015. Social perception of soil conservation benefits in Kondoa eroded area of Tanzania. International Soil and Water Conservation Research 3:183-195. https://doi.org/10.1016/j.iswcr. 2015.08.001.

Silvano RAM, Udvardy S, Ceroni M, Farley J. 2005. An ecological integrity assessment of a Brazilian Atlantic 
Forest watershed based on surveys of stream health and local farmers' perceptions: Implications for management. Ecological Economics 53:369-385. https://doi.org/10.1016/j.ecolecon.2004.12.003.

Sodhi NS, Acciaioli A, Erb M, Tan AK-T. 2008. Biodiversity and Human Livelihoods in Protected Areas: Case Studies from The Malay Archipelago. Cambridge: Cambridge University Press.

Sodhi NS, Lee, TM, Sekercioglu CH, Webb EL, Prawiradilaga, DM, Lohman DJ, Pierce NE, Diesmos AC, Rao M, Ehrlich PR.2010. Local people value environmental services provided by forested parks. 2010. Biodiversity and Conservation 19(4):1175-1188. https://doi.org/10.1007/s10531-009-9745-9.
Sotirov M, Blum M, Sorch, Selter A, Schrami U. 2016. Do forest policy actors learn through forward-thinking? Conflict and cooperation relating to the past, present and futures of sustainable forest management in Germany. Forest Policy and Economics. In Press.

Tortop HS. 2012. Awareness and misconceptions of high school students about renewable energy resources and applications: Turkey case. Energy Education Science and Technology Part B: Social and Educational Studies (4):1829-1840.

Wells M, Brandon K. 1992. People and Parks: Linking Protected Area Management with Local Communities. Washington DC: Word Bank, World Wildlife Fund, USAID. 